\title{
The Central City Insurance Crisis: Experience Under the Urban Property Protection and Reinsurance Act of 1968
}

The urban riots of the mid-1960's spurred a national recognition of, and concern for, the insurance crisis in our cities. ${ }^{1}$ The riots demonstrated the need to insure the central cities against civil disturbances and, more importantly, brought forth the realization that unless all urban property owners were protected against loss, attempts at urban rehabilitation and revitalization were doomed to failure. ${ }^{2}$ However, the means to accomplish these goals-property insurance -was largely unavailable in the inner cities. In response to this dilemma Congress enacted the Urban Property Protection and Reinsurance Act of $1968^{3}$ to assist the states and the insurance industry to make essential property insurance coverage more readily available to innercity areas. Experience under the Act reveals that this purpose is not being effectuated. This comment examines the operation of the statute to discern the theoretical and practical restraints on its effective operation and considers alternative proposals for legislative reform.

\section{The Problem}

The central city insurance problem of the 1960's derived from the inability of many ghetto businessmen and residents to purchase property insurance, even at the increased rates occasionally available from

1 See, e.g., The President's Address to the Nation on Civil Disorders, July 27, 1967; 2 Public Papers of the Presidents of the United States 721-24 (1967). The 1965 Watts riots resulted in insured losses of $\$ 38$ million; the 1967 Detroit riot, $\$ 41.5$ million; the 1967 Newark riot, \$11 million. INSURANCE INFORMATION INSTITUTE, INSURANCE FAcTs of 1969, 44 (1969). These figures represent estimated insurance losses on fixed property only and not total property damage. Uninsured, underinsured or deductible losses are not included.

2 A 1968 report to President Johnson stated: "Without insurance, buildings are left to deteriorate; services, goods and jobs diminish. Efforts to rebuild our nation's inner cities cannot move forward. Communities without insurance are communities without hope." Prestdent's National advisory panel on Insurance in Riot-Affected areas, MeEting the Insurance Crisis of OUR Crties 1 (1968) [hereinafter cited as Hughes Report]. The Hughes Panel was headed by Governor Richard Hughes of New Jersey. Other members included former Governor of Pennsylvania William Scranton, Mayor Walter Washington of the District of Columbia, Assistant Attorney General Frank M. Wozencraft, and three leaders of the insurance industry, George S. Harris, Frank L. Farwell, and A. Addison Roberts.

312 U.S.C. $\S 1749 b b b$ (Supp. V, 1965-69) [hereinafter cited as Federal Reinsurance Act]. 
high-risk, high-premium companies. ${ }^{4}$ This situation was due primarily to the belief of the insurance industry that it was uneconomical to insure urban core properties at the rate classifications approved by state insurance rating bureaus, especially in view of the major losses possible in the event of catastrophic civil disturbance. The system of rate regulation common to most states required companies to submit fixed rate schedules for the various lines of property insurance available. ${ }^{5}$ The natural inclination of the insurers was to set insurance premium rates which would maximize their profits within this system. Since all properties within a given classification were charged the same rate regardless of risk, the companies generally were willing to insure only those properties that would be profitable at the given rate. ${ }^{6}$ When the risks in a specific area appeared to demand rates greater than the applicable rate schedule allowed, insurance companies withdrew from the area. If a major insurer actively sought to write policies in ghetto areas, the increased claim payments in these areas required the insurer to increase overall premium rates. ${ }^{7}$ This rise in premium rates would eventually price the insurer out of the lower risk market, thus forcing it to raise rates even more, due to the higher loss ratio. The insurance industry gradually divided itself into two categories: standard companies competed for the better risks, thereby excluding most ghetto areas; and second-line companies ${ }^{8}$ insured at increased rates the highrisk properties major companies refused to insure. ${ }^{9}$

This situation rapidly solidified as insurers perceived the potentially disastrous losses a major urban riot could inflict on insurers of urban

4 It was estimated that $40 \%$ of the ghetto businessmen and $30 \%$ of the residents had serious insurance problems in 1967. HUGHEs REPORT 2.

5 Rates on these lines were based on the type of structure involved. The classifications would, for example, distinguish between three-story, brick apartment houses, and onestory, frame business establishments.

6 Hughes Report 33.

7 Rate increases in most states must be approved by the State Insurance Authority before they can be put into effect. Rating laws not requiring prior approval have recently been enacted in several states. See, e.g., ILL. REv. STAT. ch. 73, § 1065.18 (1968). This does not, however, solve the urban insurance crisis. See note 77 infra.

8 Second-line or non-admitted companies are those companies which, though not authorized by a state insurance department to do business in that state, actually do business in that state through non-affiliated brokers, when admitted companies will not provide the insurance needed.

8 This result occurred because these second-line companies did not (and do not nowv) insure the better risk properties, which would allow them to spread their losses. These companies further contribute to the unavailability problem by frequent failure, due either to insolvency or illegal activity. See generally Hearings on 1970 Housing and Urban Development Legislation Before the Subcomm. on Housing of the House Comm. on Banking and Currency, 91st Cong., 2d Sess., pt. 1, at 366-67 (1970) (statement by George K. Bernstein, Federal Insurance Administrator, Department of Housing and Urban Development) [hereinafter cited as 1970 Hearings]. 
properties. The picture presented to the insurers was one of tightly grouped buildings and segregated, dissatisfied minorities. ${ }^{10}$ To insurance companies this represented not a situation of present claims that the industry could not afford, ${ }^{11}$ but rather the potentiality of a major holocaust resulting in bankruptcy. ${ }^{12}$

Standard property insurers developed several tactics to restrict the number of policies their agents could write in these high-risk centralcity areas. One of the most effective methods was "redlining." 13 This strategem entailed designation of specific areas as unqualified for any coverage, or qualified only for certain limited policies. Typically, entire neighborhoods were "redlined," without regard to the intrinsic characteristics of individual properties within the area. ${ }^{14}$

Other methods of restricting the sale of property insurance included: (1) the designation of certain types of businesses (liquor stores, cleaning establishments, drugstores) as probable "target strikes" of rioters or criminals and thus as too risky for insurance; (2) the utilization of extremely low coverage-to-value ratios; ${ }^{15}$ (3) the inclusion of large "deductible" provisions in policies; and (4) the general prohibition of Negro agents in the industry on the theory that black agents would write policies exclusively in the high-risk ghetto areas. ${ }^{18}$

10 Hughes RePORT 6.

11 See, e.g., Panel Discussion-Revitalizing Our Cities: The Urban Core Insurance Crisis, 24 ReCoRD of N.Y.C.B.A. 321, 324 (1969); Comment, Riot Insurance: Recent Developments on the State and Federal Level, 20 HAstings L.J. 1255, 1256 (1969). For a discussion of the size of the riot loss compared to other industry-absorbed losses, see HuGHES REPORT 4.

12 The property insurance exposure of a large insurance company in a major city may be in the \$1-2 billion range. Denenberg, Meeting the Insurance Crisis of Our Cities: An Industry in Revolution, 1970 INs. L.J. 205, 218. The view that major disasters were a distinct possibility was also adopted by the reinsurers of these companies and was a further reason for them abandoning the central city insurance market at an ever-increasing rate. 1968 U.S. CODE CONG. \& AD. NEWS 2952.

13 As described by one New York City insurance broker: "[M]ost companies mark off certain areas. In New York these are called K.O. areas-meaning knock out areas, in Boston they are called redline districts. Same thing-don't write the business." Hughes REPORT 30.

14 "Redlining" procedures have often been characterized as involving racial discrimina. tion. In the only reported court decision in this area, however, the cancellation of insurance by the company was upheld. A New York appellate court overturned penalties imposed by the New York State Insurance Department, and upheld the right of insurers to cancel insurance on properties located in the Harlem and Bedford-Stuyvesant sections of New York City, on the ground that despite the specific cancellation of territories or sections that were overwhelmingly Negro, such action was not illegal if motivated by business reasons and not racial hostility. British \& Foreign Ins. Co. v. Stewart, 33 App. Div. 2d 1008, 307 N.Y.S.2d 749 (1970).

15 In a typical situation a business with a resale value of $\$ 65,000$ will be covered by a single insurance company only up to the amount of $\$ 40,000$.

16 Hugres RePORT 25-26. 
The unavailability of property insurance had a twofold effect. First, to stay in business, those shopowners who decided to operate without insurance or under reduced or limited coverage were forced to pass their increased costs due to uninsured losses along to their customers. This led in turn to a further increase in "resentment and tensions between merchants and neighborhood residents, who believe[d] they [were] being victimized by profiteering and unethical business practices." 17 This resentment arguably increased the possibility of civil disturbance, focused it on looting and destroying property and, to a lesser extent, could be taken as a further impetus to the commission of individual crimes against property such as burglary, robbery and arson. ${ }^{18}$

Second, the unavailability of property insurance accelerated urban decay and abandonment. Financing for new developments and rehabilitation of older structures was impossible to obtain without adequate coverage. Insurance unavailability was also a factor in the mass abandonment of stores and apartment buildings in New York Gity, Detroit and Chicago. ${ }^{19}$ Unless property owners and possible financiers were convinced that ghetto homes and businesses would not be lost completely in the event of civil disturbance, attempts to reconstruct and revitalize our inner cities were futile. ${ }^{20}$

The central city insurance situation thus did not seem likely to rectify itself. The fear of civil disturbance made it economically infeasible for the insurance industry to assume the risk of writing ghetto policies; and since insurance availability and cost were determined by general neighborhood conditions, ${ }^{21}$ the individual property owner was powerless to affect the degree of risk associated with his particular property. ${ }^{22}$ What evolved was an accelerating cycle of wider insurance unavailability and greater neighborhood deterioration which the interaction of insurers and insured seemed unable to control.

Moreover, state legislatures and insurance administrators failed to respond to the urgency of the situation. ${ }^{23}$ Strong insurance lobbies

171970 Hearings 382 (statement by Thomas J. D'Alesandro III, Mayor, Baltimore, Md.). 18 Cf. id.

19 See Gray, Housing Tragedy-Ghost Buildings, Chicago Sun-Times, Dec. 20, 1970, at 5; 1970 Hearings 390 (statement by U.S. Representative Frank Annunzio of Illinois).

20 Panel Discussion, supra note 11, at 323.

21 For a more extended discussion of these "environmental hazards," see text at note 47 infra.

22 When considering lower risk properties on the standard market, underwriters traditionally focused on the intrinsic characteristics of the property-for example, safety of wiring, method of construction. Hughes REPORT 78.

23 The power of the states to have control over insurance within their boundaries was upheld and defined in California State Automobile Ass'n v. Maloney, 341 U.S. 105 (1951). 
were able to exert such influence on these bodies that, in effect, the insurance industry regulated itself. The result was termed a "classic case of incest." 24 Reform generally was accomplished only in crisis situations ${ }^{25}$ and reflected the industry's attitude that it (and thus the states) would not move to effectuate reforms until forced to do so by public pressure or intervention by the federal government. ${ }^{26}$

\section{The Reinsurance Act}

Responding to the recommendations of the President's National Advisory Panel on Insurance in Riot-Affected Areas, ${ }^{27}$ Congress approved the Federal Reinsurance $A c t^{28}$ as part of its omnibus housing legislation of $1968 .{ }^{29}$ The stated purposes of the Act were to:

The "exhaustive" state regulatory power established as a framework by this case cannot be impaired by Congress unless the federal legislation enacted relates directly to insurance. McCarran-Ferguson Insurance Regulation Act, 15 U.S.C. § 1012 (1964). This statute is aimed primarily at preventing indirect federal control of insurance that would conflict with state regulation.

24 Hearings on the Operation of the Urban Property Protection and Reinsurance Program Before the Subcomm. on Housing of the House Comm. on Banking and Currency, 9lst Cong., 1st Sess. 349 (1969) (statement by U.S. Representative William S. Moorhead of Pennsylvania) [hereinafter cited as 1969 Hearings].

251969 Hearings 60 (statement by Anthony Scariano, Representative, Illinois State Legislature).

26 For recent examples of this reluctance to act, see notes 87.88 and accompanying text infra; Hellman, Your Policy Is Hereby Cancelled, N.Y. Times, Nov. 8, 1970, § 6 (Magazine), at 126 [hereinafter cited as Hellman].

27 Cited as Hughes REPORT at note 1 supra.

28 Federal legislation was only one of several avenues of approach open for consideration by the Hughes Panel and various legislatures. One traditional method of restructuring the burden of loss so as to increase insurance liability has focused on transferring the loss from the insurer, and thus the insured, to the person causing the damage. Individual rioters have generally been held liable in tort for the damages they cause. See generally Note, Compensation for Victims of Urban Riots, 68 CoLum. L. Rev. 57, 77 (1968).

Another method of shifting the burden of loss away from those persons directly injured has focused on the roles municipal and county governments play in preventing and controlling these disorders. See generally Lefkowitz, Municipal Liability for Damage Caused by Riot, 35 BrookxxN L. REv. 412 (1969); Rottman, Riot Damage, Municipal Liability, and Insurance, 1968 INs. L.J. 597; Note, Legislation and Riots-Interaction, 85 BRookLYN L. REv. 472, 481 (1969); Note, Municipal Liability for Riot Damage, 16 Hastings L.J. 459 (1965).

A more novel approach, and one of more practical consequence, has been the development of Urban Area Plans designed to induce insurers to insure property in given urban areas in exchange for permission from state insurance authorities to vary their rates in those areas. For a comprehensive survey of the details and results of these plans, see HUGHES REPORT 56-79.

An alternative to the method of federally controlled relief adopted would have consisted of direct federal insurance of individual properties. Implementation of this procedure is considered at notes 105-20 and accompanying text infra.

29 Housing and Urban Development Act of 1968, Pub. L. No. 90-448, § 2-1722, 82 Stat. 476. No reference was made in the legislation to the recommendation of the Hughes 
(1) encourage and assist the various State insurance authorities and the property insurance industry to develop and carry out statewide programs which will make necessary property insurance coverage against the fire, crime and other perils more readily available for residential, business, and other properties meeting reasonable underwriting standards; and (2) provide a Federal program of reinsurance against abnormally high property insurance losses resulting from riots and other civil commotion, placing appropriate financial responsibility upon the States to share in such losses. ${ }^{30}$

To achieve these goals, Congress attempted to utilize the existing insurance structure. ${ }^{31}$ In exchange for industry participation in statewide plans aimed at providing insurance for the ghettos (FAIR Plans), ${ }^{32}$ the federal government promised to protect the insurers from catastrophic loss through a system of reinsurance..$^{33}$ States were induced to form these Plans in order to take advantage of the federal back-up reinsurance. ${ }^{34}$ In theory, everyone was to benefit. The insurance industry would profit by receiving a greater volume of premiums without the previous threat to its solvency, while ghetto property owners would profit by increased access to insurance markets.

FAIR Plans may vary, but they must contain certain minimum provisions. State inspection and rating bureaus must conduct free inspections of every property for which insurance is sought. ${ }^{35}$ The bureau must then report its findings to the property owners, who are informed (1) that the insurance will be written; or (2) that the insurance will be written, but that surcharges will be added because of specified defects in the property; or (3) that insurance cannot be writ-

Panel that the riot contingency reserves of insurance companies should be deductible in computing federal income taxes. Hughes RePORT 105-07. The Federal Reinsurance Act has been widely held to fall within the exemption of the McCarran-Ferguson Act which permits federal legislation that relates directly to insurance. See, e.g., Levi, Property Insurance for the Ghetto: $A$ Solution and a Cure, 1 UrBan LAw. 59, 66 (1969); Comment, Insurance in Riot-Prone Areas, 35 BrookLyN L. REv. 458, 465 (1965); Comment, Riot Insurance: Recent Developments on the State and Federal Level, supra note 11, at 1270.

30 Pub. L. No. 90-448, \& 1102(b), 82 Stat. 556 (1968).

31 The detailed provisions of the Act are based on a "carrot-and-stick" principle. This was part of the general theory behind the "Urban Area Plans." See note 28 supra and sources cited therein.

32 12 U.S.C. \& 1749bbb-9 (Supp. V, 1965-69).

33 Reinsurance is merely coverage that insurance companies buy to protect themselves against abnormal fluctuations in their loss experience for a given period of time. The riot losses of the mid-1960's are the kind of losses that are generally felt to require reinsurance.

34 The extent of federal and state involvement in reinsurance is thus contingent on the extent of future riot damage with the initial impact upon the states. For an outline of the mechanics of the reinsurance process, see notes $43-46$ and accompanying text infra.

35 12 U.S.C. \& $1749 \mathrm{bbb}-3(\mathrm{~b})$ (1) (Supp. V, 1965-69). 
ten because of general dilapidation, but that if certain improvements are made ${ }^{36}$ this prohibition will be removed. The Plans also must establish all-industry placement facilities whose function it is to receive insurance applications and to distribute the applications (and thus the risks) equitably among the insurers with which they do business. ${ }^{37}$ Distribution of these policy risks is made on a pro rata basis according to the dollar volume of property insurance written by the particular companies in the state during the previous year. ${ }^{38}$ The facilities are intended to shift the burden of finding property insurance away from the ghetto resident to an institutionalized structure that is geared to the task.

The reinsurance provisions of the Act apply only to riot-caused damages (not to all losses covered by the placement facilities) and become effective only after the state establishes a fund in the minimum amount of five per cent of all property insurance premiums collected by insurers during the past year. ${ }^{39}$ This fund is to be used to reimburse the Secretary of Housing and Urban Development ${ }^{40}$ for funds consumed by reinsurance losses occurring in that state in excess of:

(A) reinsurance premiums earned in that state during that reinsurance contract year plus (B) the excess of (i) the total premiums earned by the Secretary for reinsurance in that state during the preceding period measured from the end of the most recent reinsurance contract year with respect to which the Secretary was reimbursed for losses under this subchapter over (ii) any amounts paid to the Secretary for reinsured losses incurred during that same period. ${ }^{41}$

Reinsurance losses on the property insurance lines available 42 are to be shared on a sliding scale ${ }^{43}$ among (1) the insurance companies,

36 Id. § $1749 \mathrm{bbb}-3(\mathrm{~b})(5)$.

37 Id. \$ $1749 \mathrm{bbb}-4$.

$38 I d$.

39 Id. § 1749bbb-9(a)(1).

40 The Secretary of HUD [hereinafter referred to as the "Secretary"] has the responsibility of establishing and carrying out the provisions of the Act. Id. $\$ 1749 \mathrm{bbb}(\mathrm{a})$.

$41 \mathrm{Id}$. § $1749 \mathrm{bbb}-9(\mathrm{a})(1)$. Participating issuers must pay HUD a gross reinsurance premium equal to $11 / 4 \%$ of the direct premium for the lines of insurance provided under the program. Each company is required to bear losses up to an amount of direct premiums earned on reinsured lines of business before any reinsurance will be paid by HUD on claims submitted. NATIONAL UNDERWRITER, April 25, 1969, at 27.

12 The important property insurance lines designated by the Act as possible "essential property insurance lines," include "fire and extended coverage," "vandalism and malicious mischief," and "burglary and theft." 12 U.S.C. § 1749bbb-2(a)(2) (Supp. V, 1965-69). The question of which of these lines would be so considered was left to the discretion of the Secretary. Few of the FAIR Plans, however, have offered coverage on lines other than fire and extended coverage. See notes 83-88 and accompanying text infra.

43 For examples of how this sliding scale apportions losses among participating parties, 
through normal loss retention and reinsurance premiums paid to the Secretary; ${ }^{44}$ (2) the states, through the required reserve fund; ${ }^{45}$ and (3) the federal government, through the National Insurance Development Fund. 46

The Act is committed to the elimination of "environmental hazards" as a relevant criterion in determining the rates at which insurance premiums will be written. An "environmental hazard" is defined in the Act as "any hazardous condition that might give rise to loss under an insurance contract, but which is beyond the control of the property owner." ${ }^{47}$ The decision to insure must focus on conditions intrinsic to a particular property-such as safe wiring, adequate fireproofing, and age and condition of the furnace ${ }^{48}$-rather than on past area riots, general neighborhood decay, or the atmosphere of unrest that may permeate a given locality.

Viewing the Act as a whole, the most salient feature is the minimal federal involvement. "Redlining," the use of environmental hazards to determine insurance rates, and the general unavailability of essential property insurance in ghetto areas were all to be eliminated by the existence of federal reinsurance against riot-caused damage. Perhaps this strategy was understandable in light of the particular focus of the government's investigations, ${ }^{49}$ which analyzed the problem as an aberration of pre-existing underwriting experience that still could

see 1968 U.S. CodE CoNG. \& AD. NEws 2960-61. Generally, the states would not be forced to share in the losses unless such losses exceeded the sum of (l) the premiums paid by the insurance industry in that state and (2) the companies' retained losses. The federal government would not be forced to share in the losses unless the state share exceeded $5 \%$ of the aggregate property insurance premiums earned in the state during the preceding calendar year on those lines of insurance reinsured by the Secretary in that state during the current year.

4412 U.S.C. § $1749 b b b-8$ (a) (Supp. V, 1965-69). See note 41 supra.

45 See text at note 39 supra.

46 The National Insurance Development Fund (NIDF) was established by the Act to receive reinsurance premiums from the insurance industry, to make payments when necessary under the reinsurance contracts, and to repay the United States Treasury Department such funds as may have been borrowed therefrom for the reinsurance program, as provided by the Act, 12 U.S.C. \& 1749 bbb-13 (Supp. V, 1965-69).

47 Id. \$ $1749 \mathrm{bbb}-2(a)(1)$. Two years after its effective date, the Act required that reinsurance be withdrawn from any FAIR Plan in which "environmental factors" are considered. $I d$. \$ $1749 \mathrm{bbb}-9(\mathrm{a})$. Even prior to that date companies were required to notify each property owner who was declined insurance, or who was required to pay a surcharge, of the remedial action necessary to remove the surcharge or make the insurance available. Id. $\$ 1749 \mathrm{bbb}-3(\mathrm{~b})(5)$.

48 See, e.g., Illinois Inspection and Rating Bureau Forms, Fac. 3, 100M; New York Insurance Rating Organization Inspection Report Form.

49 See Hughes Report 8. The Hughes Panel did not feel that truly disastrous losses were a possibility because of the exhibited ability of the industry to absorb non-riot losses. See note 11 and accompanying text supra. 
be solved by the traditional state-industry insurance structure if given some assistance by the federal government. ${ }^{50}$ All that was needed to return to normalcy was to eliminate insurance industry concern with the possibility of disastrous losses. However, as subsequent events showed, limited federal reinsurance proved to be a weak lever with which to effect great changes.

\section{Experience Under the Act: The Illinois FAIR Plan} as a Case STUdy

FAIR Plans are now operating in twenty-six states, ${ }^{51}$ Puerto Rico, and the District of Columbia, ${ }^{52}$ and have provided over $\$ 7.5$ billion of property insurance coverage to more than 300,000 policy holders..$^{53}$ Although the Federal Insurance Administration (FIA) considers these Plans to be "effectively serving a public need," 54 the Plans have been criticized extensively by such diverse groups as the congressional sponsors of the Act and the ghetto residents whom the Plans were designed to assist.55

Perhaps the major criticism of the overall operation of these Plans is that their implementation has been followed by excessively high rates for previously "redlined" areas and by sizable premium increases for "fringe-area" properties. sb $^{\text {The }}$ problem of unavailability has evolved into its functional equivalent-unpayably high rates. An examination of the practices and policies of the Illinois FAIR Plan ${ }^{57}$ reveals the factors behind this result. ${ }^{58}$

5o Panel Discussion, supra note 11, at $1268 \mathrm{n} .83$.

51 States with operative FAIR Plans as of June 30, 1970 are: California, Connecticut, Delaware, Georgia, Illinois, Indiana, Iowa, Kansas, Kentucky, Louisiana, Maryland, Massachusetts, Michigan, Minnesota, Missouri, New Jersey, New Mexico, New York, North Carolina, Ohio, Oregon, Pennsylvania, Rhode Island, Virginia, Washington and Wisconsin. FEDERAL INSURANGE AdMinistration, REPORT ON AVATLAbILITy OF CRTME INSURANCE AND SURETY BondS IN URBan AREAS app. C (1970) [hereinafter cited as CRIME INSURANGe REPORT].

62 These 28 jurisdictions constitute $75 \%$ of the total national insurance volume. 1970 Hearings $\mathbf{3 4 2}$ (statement by George K. Bernstein, Federal Insurance Administrator).

53 Crime InsUrance Report 1. Figures are as of June 30, 1970. An estimate of current policy holders, as of October, 1970, would be 93,000. Figures supplied by Ralph J. Marlatt of the National Association of Mutual Insurance Agents.

54 CrIme Insurance REPoRT 21. The FIA is the agency within the Department of Housing and Urban Development that has responsibility for insurance regulation.

b5 See generally 1969 Hearings; 1970 Hearings.

66 Examples of premium increases exist throughout the 1969 Hearings; see, e.g., survey by Deserto Insurance Company, at 95 , which indicates that under the Illinois FAIR Plan premiums had risen 31 to $100 \%$ over past rates. For example, for $\$ 14,000$ worth of fire and extended coverage protection on a three-flat, brick apartment house, premium rates under the Facility increased to $\$ 147$ from $\$ 101$ under standard rates.

57 ILL. REV. STAT. ch. 73, \$ 1065.69 (1968).

88 The Illinois situation is fairly representative because of (1) the presence of a large 
The Illinois FAIR Plan, as required under the Federal Reinsurance Act, ${ }^{50}$ authorizes the establishment of an all-industry placement facility $^{60}$ and provides for free inspection of all properties sought to be insured under the Plan. ${ }^{61}$ The Illinois Placement Facility includes all property insurers licensed in the state, ${ }^{62}$ and these insurers share on a pro rata basis in the Facility's losses $^{63}$ and profits. ${ }^{64}$ The Facility accepts applications and determines which company is to provide the insurance. ${ }^{65}$ Policies are written for a term of one year ${ }^{66}$ and become effective upon full payment of the year's premium. ${ }^{67}$

The Placement Facility has established a general application procedure: A ghetto property owner applies to the Facility on his own, through his insurance agent or through the insurance company which previously had supplied him with coverage. Under standard Illinois procedure, no specific showing of inability to obtain coverage through admitted insurers is required to qualify for FAIR Plan coverage. ${ }^{88}$ Within fifteen days of the receipt of the application by the Facility, the property is inspected by the Illinois Inspection and Rating Bu-

urban center with an extensive surrounding metropolitan area with all the problems that are coextensive therewith, (2) the similarity of the various state FAIR Plans, and (3) the similarity of state laws regulating insurance. A corollary factor contributing to a comparative rise in rates in Illinois (and other states) was the practice of the Placement Facility of implementing a special surcharge for "hazardous conditions not otherwise charged for." Illinois Schedule of FAIR Plan Surcharges (1968). Although this practice was contrary to the intent of the Act and has now been eliminated, the Facility was able to add as much as a $100 \%$ (later $25 \%$ ) surcharge onto the "published rate" which already included Rating Bureau Surcharges. This special surcharge was applied automatically during most of the time it was in effect. 1969 Hearings 345 (statement by Elmer F. Reske, Manager, Illinois Property Insurance Placement Facility). Thus this surcharge was being applied not for the increased danger inherent in multiple deficiencies as was intended, but rather for environmental surcharges. This specific loophole has now been eliminated in all states: subsequent to the Illinois abandonment of Schedule F surcharges, the Secretary of HUD issued federal regulations stating that no surcharge shall be made on the basis of environmental hazards. 35 Fed. Reg. 12116 (1970).

59 See text at notes $35 \& 37$ supra.

60 Ilx. Rev. Stat. ch. 73, § 1065.72 (1968) (Illinois Property Insurance Placement Facility) [hereinafter referred to as the "Placement Facility" or the "Facility"].

61 Id. § 1065.71(3).

62 Id. § 1065.72. By making participation in the Plan mandatory, and thus including those property insurers not previously offering coverage in urban areas, the risk of loss is spread on a wider basis.

63 Id.

64 Id. § 1065.73(3).

65 Id. § 1065.72. See text at notes 37-38 supra.

66 Illinols Property Insurance Inspection and Placement Program Plan of OperaTION § 6(14) (1968) [hereinafter cited as ILLINoIs PLAN OF OPERATION].

67 Id. $\$ 6(2)$. If full payment is not made to the Facility within a 15-day period after it is offered, a new application and inspection must be made. $I d . \S 6(3)$.

68 Interview with Elmer F. Reske, Manager, Illinois Property Insurance Placement Facility, in Chicago, Illinois, Sept. 10, 1970. 
reau, ${ }^{69}$ and within another five days the results of this inspection are forwarded to the Facility indicating the "standard" and "published" rates for the property, and the specific defects found.70 This "published" rate is composed of the "standard" or "base" rate, ${ }^{71}$ plus surcharges for each of the defects found on the property. ${ }^{72}$ The Facility then decides on the basis of the inspection report whether the property is insurable, and if so, at what rate. The property owner is then free to purchase the insurance through the Facility at this rate, go back to the high-risk market if coverage is available there, or go without insurance entirely. ${ }^{73}$

Although insurance coverage is usually offered under the Plans, rates have skyrocketed. ${ }^{74}$ The change in rating procedures explains in part this price increase. At the national level, inspection of urban properties was rare prior to the advent of the riots and the subsequent

09 An inspection and rating bureau was to be designated by the Placement Facility with the approval of the Illinois Insurance Director. IlL. REv. STAT. ch. 73, \& 1065.70(2) (1968). The Illinois Inspection and Rating Bureau is the official inspection agency in Illinois. It also establishes the "published" rate for properties, which is then communicated to the Facility.

To An example of the use of this process was given by the Illinois Department of Insurance in its report on the FAIR Plan of February 10, 1969: "For instance, a department store after inspection may be found to have poor wiring and congested spaces. The inspector may charge $\$ 0.10$ per $\$ 100$ for each of these items [each up to a maximum of $100 \%$ of the standard rate] and the facility in turn may apply a factor that would increase these items to a total of $\$ 0.30$ [per $\$ 100]$ due to the fact that the existence of both conditions increases the hazard beyond the separate existence of these items." 1969 Hearings 194.

71 The "standard" rate is the rate charged on the same type structure exclusive of extra charges for location or structural defects.

72 Surcharges are applicable for faults or inadequacies in the following areas: Schedule A: building condition, construction and repair; Schedule B: condition of occupancy and premises; Schedule C: building access and internal exposure; Schedule D: power, heating or wiring; Schedule E: miscellaneous. Schedules A through $\mathrm{C}$ could be assessed each to a maximum of $100 \%$ of the base rate. These surcharges can be eliminated by making the improvements outlined on the inspection report.

73 As of August 31, 1970, the Illinois Facility had received 49,646 applications for insurance through the Illinois FAIR Plan. Of these applications, 3,193 were withdrawn, 42,040 were accepted and assigned to companies, 1,971 were declined and 3,945 were in the process of being reviewed. Figures supplied by Elmer Reske, Manager, Illinois Property Insurance Placement Facility. No data is available on the rate and frequency of surcharges or on the number of policies "dumped" into the Facility.

74 Rates have increased for ghetto properties since the time of the riots. Rate increases for fringe area properties are measured from the period immediately before the adoption of the Plans. Assessments of the size of increase of these premium rates have varied, but have generally been in the 200 to $400 \%$ range. See, e.g., 1969 Hearings 2 (statement by U.S. Representative Frank Annunzio of Illinois); 1969 Hearings 7 (statement by U.S. Representative Leonor Sullivan of Missouri); 1969 Hearings 59 (statement by Anthony Scariano, Representative, Illinois State Legislature); 1970 Flearings 337 (statement by U.S. Senator Joseph $D$. Tydings of Maryland). Some estimates of the possible increases in rates have been substantially higher; see 1969 Hearings 97, 265. 
disappearance of insurance coverage. ${ }^{75}$ In Illinois, rates were generally established on a class basis ${ }^{76}$ according to standards established by the rating bureau. ${ }^{77}$ Inspections were infrequent, due, first, to the costcutting procedures of the standard companies, ${ }^{78}$ and second, to the incomplete reports filed by private agents, who feared that policies would not be written if defects in the properties were fully disclosed. Today, however, the FAIR Plans provide free inspections. ${ }^{79}$ At no cost, insurance companies are able to ascertain from a state agency the condition of a property, including any specific deficiencies, before writing a policy. Since surcharges are now added for specific inadequacies, ${ }^{80}$ many owners find their policies to be as much as three or four times as expensive as before the riots. ${ }^{81}$ In addition, those ghetto property owners who can least afford the insurance are least able to afford the improvements that would remove these surcharges. ${ }^{82}$

Another major problem is the limited number of lines available under the FAIR Plans. Although there has been a recent move toward inclusion of vandalism and malicious mischief coverage through the facilities, ${ }^{83}$ most states still offer only standard fire policies with ex-

751969 Hearings 13-14 (statement of William B. Ross, Deputy Under-Secretary and Acting Federal Insurance Administrator, Department of Housing and Urban Development).

761969 Hearings 202 (statement by William S. Gibson, Illinois Department of Insurance); see text at notes 6-7 supra. Residential risks were inspected to a much lesser extent than commercial properties. 1969 Hearings 202.

77 In the summer of 1969 the Illinois legislature passed a free rating bill for private property insurers. ILL. REv. STAT. ch. 73, \& 1065.18 (1969). This bill, which became effective January 1, 1970, allows companies to put their rate schedules into effect without the prior approval of the insurance commissioner and permits them to establish different rates for different areas. The bill will work to some extent to remove the division of the market between standard and substandard companies and should eliminate the earlier problem of "unavailability at some price." It does not, however, act to solve the problem of unpayably high rates, and has been seen as possibly aggravating this situation. IrLINors GENERAL Assemblx, RePort of THE JoINT InsURANCE Study CoMmitTEe 18 (1969).

78 See, e.g., 1969 Hearings 14 (statement by William B. Ross, Deputy Under-Secretary and Acting Federal Insurance Administrator).

79 See text at note 35 supra.

80 See note 74 supra. The increased rates were due to the application of several or all of these surcharges to their maximum assessment.

811970 Hearings 332 (statement by U.S. Representative Frank Annunzio of Illinois, based on surveys of more than 150 properties in Chicago in 1969 and 1970); 1969 Hearings 65 (statement by U.S. Representative Abner Mikva of Illinois). These surveys, while not conclusive in themselves, are reflective of the general extent of the increase in rates under the FAIR Plans as opposed to prior base rates.

82 One method of remedying this problem was contained in $\$ \$ 503(d)$ and $509(c)$ of the Housing and Urban Development Act of 1968, 82 Stat. 521, 523, which provided for rehabilitation grants and loans for ghetto property owners. These provisions apparently have not, however, been used extensively. 1969 Hearings 50 (statement by Charles Wiecking, Office of the Federal Insurance Administrator).

83 A regulation issued pursuant to $\S 1749 \mathrm{bbb}-2(a)(2)$ of the Federal Reinsurance Act was 
tended coverage endorsements. ${ }^{84}$ And crime insurance, the coverage ghetto residents need most urgently, ${ }^{85}$ was not even included in the Federal Reinsurance Act, because the industry successfully argued that it "was well equipped to handle this kind of coverage on its own."86 Thus, crime insurance, if available at all, is obtainable only at extremely high rates in most urban centers ${ }^{87}$ and is subject to the same "redlining" procedures that were previously applied to fire insurance coverage. ${ }^{88}$

The contention that the Federal Reinsurance Act and the state FAIR Plans have failed to improve ghetto insurance conditions has not gone unchallenged. While admitting that some minor problems existed in the initial operation of the Plans, ${ }^{89}$ the Federal Insurance Administration, the Illinois Insurance Authority, and other defenders of the Act argue that the property insurance situation has become demonstrably more equitable, as evidenced by the large number of policies written through the Plan and the relatively low number of

adopted by the Federal Insurance Administration on July 29, 1970, designating vandalism and malicious mischief coverage as "basic property insurance" to be offered by the FAIR Plans. 35 Fed. Reg. 12115 (1970). This provision was already required through the FAIR Plans in eleven jurisdictions: California, Connecticut, Illinois, Iowa, Kentucky, Maryland, Massachusetts, New Jersey, New Mexico, Puerto Rico and Wisconsin. Crime Insurance REPORT 22 n.21.

$8 \pm$ Under the Illinois FAIR Plan, for example, up until 1970 "basic property insurance" included only "coverage against direct loss to real and tangible personal property at a fixed location provided in the standard fire policy and extended coverage endorsement." ILIINOIS Plan of Operation 2(1).

85 Cole, Wanted: Crime Insurance, N.Y. Times, Oct. 18, 1970, \& 3, at 1. Comparing 1968 and 1960 figures, crimes against property were $124.2 \%$ higher, burglary was $103.8 \%$ above the 1960 level, and robberies were 143.7\% higher. CRIME INSURANCE REPORT 25.

861970 Hearings 332; 116 CoNG. REc. H7661 (daily ed. Sept. 8, 1969).

87 For the resultant increase in insurance premiums, see the comparative survey of premium rates in CRIME INSURANCE REPORT app. J. For example, in New York a typical furniture-store owner paid $\$ 551$ for $\$ 15,000$ worth of burglary coverage in 1962 and $\$ 1,207$ for the same coverage in 1969. See 1970 Hearings $387-39$ (statement by U.S. Senator Joseph D. Tydings of Maryland) and 424-26 (National Association of Mutual Insurance Agents Crime Insurance and Surety Bond Availability Survey).

88 CRIME INSURANCE REPORT 35. An additional problem that ghetto residents have faced in obtaining crime insurance has been the increased sophistication of the industry in determining rating classifications for this line, as compared with that evidenced for fire insurance coverage. For example, grocery stores are classified separately from cleaning establishments and their respective rates are based on the experience of each group. This is a refinement of the "target-strike" procedure used previously for fire coverage, see text following note 15 supra, and places an increased insurance burden on specific types of businesses. Crime Insurance Report 63.

89 Delay in processing the applications, the absence of information concerning the Plan and the overuse of the "other hazardous conditions" surcharge, have been the "start-up" problems most frequently mentioned. See, e.g., 1969 Hearings 192 (statement by James Baylor, Illinois Director of Insurance). 
rejections..$^{90}$ However, the large number of policies apparently is due in part to the increased incidence of "dumping" previously insurable "fringe area" properties into the Plans, and the small number of rejections may be due to the unwillingness of property owners who cannot afford the higher rates (due to surcharges) to apply to the Facility for coverage at all. ${ }^{91}$

Thus, if the underlying goal of the Federal Reinsurance Act was to eliminate the unavailability of "essential" property insurance, ${ }^{92}$ the Act as formulated has proven to be largely inadequate. The drafters of the Act failed to appreciate that insurance "availability" is inextricably entwined with the cost of insurance. No direct control over rates was given to the Secretary, ${ }^{93}$ and no subsidies were made directly available to mitigate the substantially increased rates. By concentrating on coverage availability rather than on rating policies, ${ }^{94}$ the Act has failed to alleviate the pressure on ghetto residents and businessmen to leave urban centers. Unpayably high rates are as much a cause of insurance unavailability as are "redlining" and "blacklisting."

While the Act has not provided the required assistance to its intended beneficiaries, the inner cities, it has been a boon to the insurance companies. The establishment of state FAIR Plans has: (1) eliminated the risk of carrying unreinsured urban areas contiguous to riot-prone districts; (2) provided the free inspection of individual properties which was economically infeasible before; (3) given the companies freedom to charge higher rates on FAIR Plan insured prop-

s0 As of March 31, 1970, including new and renewal applications, the FAIR Plans have written 405,112 policies and declined insurance on 41,421 properties. Figures supplied by Charles Wiecking, Federal Insurance Administration. The FIA has not, however, been getting the statistical information from the Plans that would enable it to judge the effectiveness of the Reinsurance Amendment. 1970 Hearings 350 (statement by George K. Bernstein, Federal Insurance Administrator). Many of the state FAIR Plans have told the FIA that the data requested on losses, total amount of paid claims, premiums written, etc., are "not available" and "none of our [the FIA's] business." Id. at 353. There has been no way to gauge accurately the number of policies presently in effect, or whether or not the Placement Facilities were operating at a profit or a loss. Id.

91 See 1969 Hearings 87 (statement by Otis Collins, Representative, Illinois State Legislature); National UNDERWRTtER, Sept. 11, 1970, at 6.

92 See text at note 31 and text following note 3 supra.

93 Rate control was left to the state insurance authorities. If the rates were seen to violate the goals of the FAIR Plans, then the reinsurance could be withdrawn. 1969 Hearings 48 (statement by Charles Wiecking, Office of the Federal Insurance Administrator). This has not, however, happened. No specific authority was given to the Department of Housing and Urban Development to review the rates or the surcharges for reasonableness. The rates merely had to be based on individual properties. Id. at 49.

941969 Hearings 185 (statement by U.S. Representative Frank Annunzio of Illinois). But cf. 1970 Hearings 350 (statement by George K. Bernstein, Federal Insurance Administrator).

95 See text at notes 13-14 supra. 
erties with the assent of the state insurance authorities; ${ }^{96}$ and (4) allowed them to lower their personnel expenses ${ }^{97}$ because of lower agent commissions through the facilities. ${ }^{98}$

\section{Proposals for Reform}

\section{A. The Crime Insurance Amendment}

The 91st Congress, in Title VI of the Housing and Urban Development Act of 1970,99 has adopted two reforms intended to alleviate the central city insurance problem. First, the Secretary is authorized to provide crime insurance directly through the facilities of the federal government if he finds that the state involved is experiencing a "critical market unavailability situation" 100 for this line. Such coverage is to be made available at an "affordable rate"101 and is to be implemented through utilization of government employees, industry employees, or both, as fiscal agents of the United States. ${ }^{102}$ Second, the Amendment authorizes the establishment of an Office of Review and Compliance ${ }^{103}$ to gather information on the workings of the state FAIR Plans and to assist them in carrying out the provisions of the Act.

The Crime Insurance Amendment, while evidencing a modicum of concern for the unavailability problem, can nevertheless be criticized

96 At least in Illinois this factor has been eliminated to some extent by the new rating laws. See note 77 supra.

97 As noted by Manfred Spindel, President of Spindel Insurance Company of Chicago, "The fire [insurance] companies are using the Illinois Placement Bureau for coverages outside the ghetto area and telling their agents or brokers to put their business through the Placement bureau-why not? Why pay their agents commissions of 25 or 30 percent when they will all share in the fire insurance being placed with an acquisition cost of 8 percent?" 1969 Hearings 375. Lower agent commissions through the Facilities have also led to an unwillingness on the agent's part to spread information about the FAIR Plans to large numbers of property owners. See, e.g., 1970 Hearings 339 (statement by U.S. Senator Joseph D. Tydings of Maryland).

98 Commissions paid to agents through most FAIR Plans have been in the 8 to $10 \%$ range and have been less than one-half what they would normally be through the standard market. See, e.g., New Jersey Insurance Underwriting Ass'N, Plan of Operation K(I) (1968); ILLINOIS PLAN OF OpERATION § 11.

09 Pub. L. No. 91-609, 84 Stat. 1770 (1970) [hereinafter cited as Crime Insurance Amendment]. For the tangled legislative history of this statute, see note 105 infra.

100 Crime Insurance Amendment § 1281(b). Direct coverage under the new provision is not available to properties which the Secretary deems to be uninsurable or with respect to which "reasonable protective measures to prevent loss, consistent with standards established by the Secretary, have not been adopted." Id.

101 Id. "Affordable rate" is defined as: ". . . such premium rate as the Secretary determines would permit the purchase of a specific type of insurance coverage by a reasonably prudent person in similar circumstances with due regard to the costs and benefits involved ...." Id. \& 1203(a)(1).

$102 I d . \$ 1232$.

$103 I d$. \& 1215 . 
on several grounds. Of initial importance is that the Amendment is unlikely to achieve even the limited goals it posits for itself. The Amendment's failure to define "affordable rate"104 exhibits to the insurance industry, the states, and the Federal Insurance Administration a congressional unwillingness to make any specific commitment to alleviating even crime insurance unavailability. Of more general significance in the Amendment, however, is its failure to address itself to the question of affordable rates for other essential lines. The direct insurance provisions of the Amendment are applicable only to burglary and theft coverage and do not deal with fire and extended coverage, or vandalism and malicious mischief.

\section{B. Direct Federal Insurance}

One possible alternative to the existing legislation would be for Congress to fill the two major gaps in the Crime Insurance Amendment -the failure to define "affordable rate" and the limited number of lines for which direct coverage is available. Legislation ${ }^{105}$ along these

104 See note 101 supra.

106 In 1969 and 1970 similar legislation was put before Congress which would have corrected most of the defects of the Reinsurance Act and its amendments. H.R. 13666, 91st Cong., Ist Sess. (1969); H.R. 19436, 9lst Cong., 2d Sess., tit. VII (1970) [hereinafter cited as Annunzio Bill]. It was, however, rejected in favor of the adopted Crime Insurance Amendment. The Annunzio bill would have established a cut-off point for the implementation of direct federal insurance at $175 \%$ of the applicable base rate, rather than $100 \%$ of the base rate, in an attempt to account for the admittedly deteriorated condition of most central city properties. Annunzio Bill § 702(c)(1). It would also have included as essential property lines for purposes of direct insurance and FAIR Plan coverage, fire and extended coverage, vandalism and malicious mischief, and burglary and theft. Id. \& 703. It would thus have eliminated that portion of the Act which gives the Secretary the duty of determining which lines of coverage would be included under the FAIR Plans as "basic property insurance." Other supplementary reforms contained in the Annunzio bill were: 1) a requirement that agents' and brokers' commissions through the FAIR Plans be equal to those through the private market, 2) elimination of state sharing in riot loss payments, and 3) provision for rehabilitation grants and loans on property insurable only at unreasonable rates. $I d . \$ \S 705,708,710$.

Several other bills concerned with insurance unavailability were introduced in Congress in 1970. S. 4368, the Sparkman bill, which contained the provisions adopted in the Crime Insurance Amendment, was introduced at about the same time as the Annunzio bill. The Sparkman bill passed the Senate on September 23. The House sponsors of the Annunzio bill, seeing that the bill in its present form would not pass both houses of Congress, submitted an amendment in the nature of a substitute, the Stephens bill (carrying the same H.R. number). 116 CoNG. REc. HI1011-12, H11027 (daily ed. Dec. 2, 1970). This bill, which differed from the Sparkman bill only in effective authorization date and a requirement for equal agent commissions, withstood several attempts to eliminate the crime coverage and direct insurance provisions completely, and finally passed the House on December 3. 116 Cong. REc. HIll10 (daily ed. Dec. 3, 1970). On December 8, the Stephens bill came before the Senate; after striking all after the enacting clause and substituting therefor the Sparkman bill, the Stephens bill was passed. At this point a Conference Committee was formed in which it was agreed to accept the, 
lines would provide direct federal insurance on all three essential property lines to all property owners in a state whenever such coverage becomes available only at more than normal base rates through either the FAIR Plans or the private market.

Such direct federal insurance would either induce companies to shift their resources to ghetto areas in an attempt to improve the available coverage and maintain the dominant private role, or it would force the government to assume direct responsibility in lieu of private action. This type of pressure is not likely to cause insurers to insure in ghetto areas at less oppressive rates, since the income the insurers would derive therefrom would be less than they could realize through concentrating their resources elsewhere. ${ }^{106}$ If the industry does not return to ghetto areas there will be an additional cost placed on taxpayers. While the costs of the direct insurance program are likely to exceed the amounts paid in premiums, these expenses are in effect the short term costs of permitting rehabilitation to begin. To the extent that central city problems are overall societal problems, this is an expense that taxpayers generally should bear. ${ }^{107}$ If these costs can be kept to a minimum by regulation requiring simple, minimal-cost, loss-prevention standards such as adequate locks and window bars to reduce crime risks, then there is even more reason for these temporary costs to be borne in this manner. ${ }^{108}$

The arguments against direct federal insurance are the usual ones directed against federal involvement in any field traditionally left to the private sector of the economy: that action by the federal government is intrinsically less efficient and more costly than private action; ${ }^{109}$ that the federal government is becoming too monolithic and is performing too many economic functions; ${ }^{110}$ and that to allow federal Senate version of H.R. 19436. H.R. REP. No. 1784, 91st Cong., 2d Sess. 21-25 (1970). This agreed-on bill passed the Senate and House on December 18 and 19, respectively, and was signed into law on December 31, 1970, by President Nixon.

106 See notes 117-18 and accompanying text infra.

107 See W. Heller, NEW DIMENSIONS OF Political ECONOMY ch. III (1966); E. ReDFord, D. Truman, A. HACkeR, A. Westin \& R. Wood, Politics and Government in The UNited States ch. 29 (1965); Vernon, The Myth and Reality of Our Urban Problems, in CiTY and Suburb: The Economics of Metropolitan Growth 97 (B. Chinitz ed. 1964).

108 These kinds of standards could have been developed and promoted by the industry, but, in accord with its general practice of resisting change, they never were. See notes 25-26 and accompanying text supra. These standards are being developed elsewhere, however. In Oakland, California, for example, the Burglary Prevention Ordinance, OAKLAND, CAL., REv. MUN. CODE § 3-12.08 (1964), requires that business property owners provide for a variety of precautions: adequate locks, non-removable door-hinge pins, window bars. The ordinance has significantly reduced burglaries in the area. CRIME INSURANCE REPORT 92 n.72.

109 Cong. Rec. Hll011 (daily ed. Dec. 2, 1970).

110 See, e.g., United States Library of Congress, Contributions of Science and Tech- 
intervention would provide a disincentive for private groups and the states to assume the necessary responsibility. ${ }^{111}$ These feelings played a major role in several attempts to block direct federal insurance. ${ }^{112}$

These general objections to direct insurance are not, however, unanswerable. First, one can no longer argue with any substance that the federal government should not get into the business of providing insurance. It is already the nation's largest insurer, ${ }^{113}$ providing protection, for example, for a variety of institutions and concerns ranging from banks and savings and loan associations to farms and credit unions. ${ }^{114}$ Even insurance companies are seeking legislation that would require the government to insure them against losses. ${ }^{115}$ Second, the insurance industry, in collaboration with state governments, has shown little interest in investing money or personnel in these essential property lines. ${ }^{116}$ The willingness of the industry to write coverage on property lines in rural and suburban areas has not carried over to urban core areas where the coverage is most needed. The proposition that such an investment would assist in rehabilitating the ghetto areas and would lower risks (and thereby make coverage available at rates both affordable to property owners and profitable for the industry), has not appeared sufficiently advantageous to the companies to induce them to act. ${ }^{117}$ This seems to leave the problem of unavailability, if it is to be solved at all, to the federal government.

The final question concerning direct insurance is whether it should be withdrawn once rehabilitation has proceeded to the point at which the industry has enough confidence in the rehabilitated central city areas to offer coverage at payable rates, ${ }^{118}$ or whether government should permanently supplant the private companies so as to prevent the development of some future unavailability problem. The trend has

nology to Federad Crime Insurance 56 (1967); Kimball, The Case for State Regulation of Insurance, in Insurance, Government and Social Policy: Studies in Insurance ReguLATION 414-47 (S. Kimball \& H. Denenberg eds. 1969).

111 H.R. REP. No. 1556, 91st Cong., 2d Sess. 187 (1970).

112 See sources cited in note 105 supra and in H.R. RER. No. 1556, 91st Cong., 2d Sess. 181, 187-88 (1970).

113116 Conc. Rec. Hll015 (daily ed. Dec. 2, 1970).

114 Id. See also Cole, Wanted: Crime Insurance, N.Y. Times, Oct. 18, 1970, § 3, at 1; HUGHES REPORT 109-13.

115116 CoNG. REc. H11015 (daily ed. Dec. 2, 1970).

116 Hellman, supra note 26, at 124 .

117 Property and casualty insurers presently have available a record \$142 billion surplus reserve (cash left over after making provision for maximum projected payout). Because companies are under no obligation to maintain these reserves, they are establishing holding companies to escape governmental restriction on how they can spend this money. Id.

118 The Crime Insurance Amendment and Annunzio Bill are based on this premise. 
definitely been toward the latter of these alternatives. ${ }^{119}$ As stated by the FIA's George Bernstein, the problem ". . . of where insurance comes from is less important than that people get it."120 Unfortunately, however, the question of weighing the benefits of federally controlled insurance against the disadvantages caused by the displacement of the private insurance industry is precluded by the small likelihood of Congress taking one major step rather than a series of short shuffling ones.

\section{Insurance as a Public Utility}

A further alternative solution to the unavailability problem concerns the concept of insurance as a public utility. ${ }^{121}$ It could be argued that the public need for insurance ${ }^{122}$ is so universal and basic that this service can no more be denied to persons by insurers than can gas, telephone service or electricity by public utility enterprises. Thus, as a condition of doing business, insurance companies would be required to provide coverage at the same rate to all residents of the city.

A primary consideration in measuring the viability of this approach is whether the burden of providing insurance coverage to all customers at an equitable rate can be borne by insurance companies. As in most public utility enterprises, there can be expected a decline in rate funds taken in. The industry maintains that it has suffered substantial losses over the past several years on all property lines ${ }^{\mathbf{1 2 3}}$ and that the state placement facilities, which it funds, have drained the industry's

110 This trend is evidenced by the progression from the unregulated status of the industry prior to the 1930's, through the dominance of the state-industry position prior to 1968 when the Act was adopted, to the recent passage of the Crime Insurance Amendment providing for limited direct federal insurance.

120 Main, Why Nobody Likes the Insurers, ForTune, Dec. 1970, at 121 [hereinafter cited as Main].

121 Denenberg, Mreeting the Insurance Crisis of Our Cities: An Industry in Revolution, 1970 INs. L.J. 205, 210-11 (1970); cf. Comment, Insurance Ratemaking Problems: Administrative Discretion, Investment Income, and Prepaid Expenses, 16 WAYNE L. REv. 95,133 (1969). The process of disseminating insurance is moving toward meeting the standard test of public utility status: "If a business is (l) affected with a public interest, and (2) bears an intimate connection with the ... [process of] distribution, and (3) is under an obligation to afford its facilities to the public generally, upon demand, at fair and non-discriminatory rates, and (4) enjoys, in a large measure an independence and freedom from business competition brought about either (a) by its acquirement of a monopolistic status, or (b) by the grant of a franchise or certificate from the State placing it in this position, it is ... a public utility. . . Davies Warehouse Co. v. Brown, 137 F.2d 201, 217 (Emer. Ct. App. 1943) (emphasis in original); accord, Davies Warehouse Co. v. Bowles, 321 U.S. 144, 148 (1943).

122 The ferment that is occurring in the property insurance field is also occurring in other insurance lines. For a comprehensive survey of the movement in other lines, see Insurance Symposium, $57 \mathrm{KY}$. L.J. 627 (1969).

123 See, e.g., Main, supra note 120, at 83-86; Heliman, supra note 26, at 124. 
resources. ${ }^{124}$ Several factors, however, would seem to mitigate this bleak financial picture. Of major importance is the large profit brought in by insurers on non-property lines of insurance. No major American insurer lost more on its unprofitable coverages in 1969 than it made on its healthy lines, such as workmen's compensation, and through investment return on its financial reserves. ${ }^{125}$ In New York, for example, 1968 figures show that insurers broke even on underwriting and accumulated a $\$ 3$ billion return on investment of accumulated returns. ${ }^{126}$

Moreover, the FAIR Plans have not as yet been the losing proposition that insurers have indicated them to be. ${ }^{127}$ In addition to the direct benefits to the industry listed earlier, ${ }^{128}$ companies have derived some indirect gains from the Plans. For example, in Illinois, one of the few states from which any data is available, the Facility Combined Operating Ratio (based on funds expended over funds actually paid out), which is relied on by the industry to show the amount of loss involved, does not take into account the substantial dollar amounts taken in by the companies on state-permitted, state-wide rate increases before the open rating laws were adopted. ${ }^{129}$ In addition, whatever losses the Facility might have incurred are due to a considerable extent to start-up expenses involved in establishing a new facility and are not expected to continue. ${ }^{130}$ Thus, the insurance companies seem capable of carrying the financial burden of a public-utility-type operation.

124 See Hellman, supra note 26, at 125; Illinois Property Insurance Placement FACILITY, AcCOMPLISHMENTS OF THE IlLINOIS FAIR PLAN app. B (1970); 1970 Hearings 353.

126 Hellman, supra note 26 , at 124 . Further operating to lessen the extent of industry losses are the reinsurance provisions of the Act protecting the insurers from catastrophic riot loss.

126 Id. On a single-insurer basis, Continental Insurance Company, for example, in 1969 suffered a net underwriting loss of $\$ 4$ million, but brought in a return of $\$ 88$ million on outside investments. Id. For a discussion of the analysis involved in gauging underwriting profit and loss for rate determinations, see Comment, Insurance Ratemaking Problems: Administrative Discretion, Investment Income, and Prepaid Expenses, 16 WAYNE L. REV. 95, 101-27 (1969), indicating that the accounting practices of the insurance industry distort industry loss claims to the disadvantage of the potential insured. Id. at 133.

127 Although a large number of ghetto properties have been insured through the Plans to date, the adoption of a complete program of insurance might impose increased liability for a short time that might have to be alleviated by governmental subsidy.

128 See text at notes 96.98 supra.

129 Chicago Daily News, Apr. 23, 1969, at 14. See note 78 supra.

130 See, e.g., 1969 Hearings 192; Illinols Property Insurance Plagement Facility, Accomplishments of THE ILInois FAIR PLAN app. B (1970). Notice the proportionately large size of the "Other Underwriting Expenses Incurred." The loss experience of the Facilities has not demonstrated that they are much less efficient than most private insurers. Compare Main 119-20. 
The adoption of the insurance-as-a-public-utility approach has certain advantages. Such an approach focuses the attention of regulators on the availability of insurance to all potential customers at a strictly limited price irrespective of the condition of the property to be insured. This spreads the risk more widely and facilitates rehabilitation of ghetto properties by providing a secure base for renovation investment.

\section{ConCLUSION}

The Federal Reinsurance Act has failed to eliminate insurance unavailability in urban areas, and the primary goal of rehabilitating our central cities cannot be accomplished or even substantially begun until such protection is provided. While the recently enacted Crime Insurance Amendment is a step in the right direction, it does not apply to needed lines other than crime insurance, nor does it provide any indication of how far Congress is willing to go in rehabilitating ghetto areas through the private insurance mechanism. These deficiencies could possibly be eliminated to a significant degree by either providing a more complete direct federal insurance system or by transforming the private insurance mechanism into a public utility enterprise. Rehabilitation will not occur until these deficiencies are eliminated. 


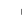

